\title{
Prediction of DOM removal of low specific UV absorbance surface waters using HPSEC combined with peak fitting
}

\author{
Linan Xing ${ }^{1}$, Rolando Fabris ${ }^{2}$, Christopher W. K. Chow ${ }^{1,2,3}$, \\ John van Leeuwen ${ }^{1,3}$, Mary Drikas ${ }^{1,2,3}$, Dongsheng Wang ${ }^{1,3, *}$ \\ 1. State Key Laboratory of Environmental Aquatic Chemistry, Research Center for Eco-Environmental Sciences, Chinese Academy of Scineces, \\ Beijing 100085, China.E-mail: wgds@rcees.ac.cn \\ 2. Australian Water Quality Centre, South Australian Water Corporation, 250 Victoria Square, Adelaide, South Australia 5000, Australia \\ 3. SA Water Centre for Water Management and Reuse, University of South Australia, Mawson Lakes, South Australia 5095, Australia
}

Received 23 September 2011; revised 22 November 2011; accepted 24 November 2011

\begin{abstract}
High performance size exclusion chromatography (HPSEC) is used in water quality research primarily to determine the molecular weight distribution of the dissolved organic matter (DOM), but by applying peak fitting to the chromatogram, this technique can also be used as a tool to model and predict DOM removal. Six low specific UV absorbance (SUVA) source waters were treated using coagulation with alum and both the source and treated water samples were analysed using HPSEC. By comparing the molecular weight profiles of the source and treated waters, it was established that several DOM components were not effectively removed by alum coagulation even after high dosage alum treatment. A peak-fitting technique was applied based on the concept of linking the character (molecular weight profile) of the recalcitrant organics in the treated water with those of the source water. This was then applied to predict DOM treatability by determining the areas of the peaks which were assigned to removable organics from the source water molecular weight profile after peak fitting, and this technique quantified the removable and non-removable organics. The prediction was compared with the actual dissolved organic carbon (DOC) removal determined from jar testing and showed good agreement, with variance between $2 \%$ and $10 \%$. This confirmed that this prediction approach, which was originally developed for high SUVA waters, can also be applied successfully to predict DOC removal in low SUVA waters.
\end{abstract}

Key words: DOM; high performance size exclusion chromatography; peak fitting; water treatment DOI: $10.1016 / \mathrm{S} 1001-0742(11) 60923-6$

\section{Introduction}

The drinking water industry faces many challenges in attempting to maintain and improve water quality to meet increasingly stringent regulations. There has been an increasing emphasis on water quality improvement, and operators of water utilities have become more aware of the impact of dissolved organic matter (DOM) on their treatment processes. DOM is a complex matrix of heterogeneous organic material which is derived from decaying terrestrial vegetation and aquatic organisms (Andersen et al., 2000; Del Vecchio and Blough, 2004; Lankes et al., 2008). While its presence in source waters poses little health risk, it can be problematic in the production of drinking water and is a major influence in determining both coagulant and disinfectant doses. Furthermore, DOM provides precursors for the formation of disinfection byproducts (DBPs) and can also act as a carbon food source for bacterial growth in distribution systems (Uyak et al., 2008). Effective removal of DOM prior to disinfection can

\footnotetext{
* Corresponding author. E-mail: wgds@ rcees.ac.cn
}

minimize the formation of disinfection by-products and reduce the disinfectant dose required to control bacterial regrowth with increased penetration into the distribution system.

The concentration of DOM and also its character are important in many instances, including for the estimation of a coagulant dose and the dose efficiency. For a better understanding of the types of organic compounds present before and after treatment, a number of characterization techniques have been employed. High performance size exclusion chromatography (HPSEC) has proved to be a useful tool for evaluating various water treatment processes (Vuorio et al., 1998; Nissinen et al., 2001; Reemtsma et al., 2008). The change in DOM character can be determined by comparing DOM profiles before and after treatment (Bolto et al., 1999; Chow et al., 1999; Gjessing et al., 1999; van Leeuwen et al., 2002). This approach has been utilised to investigate the impact of DOM on processes such as coagulation, disinfection and biodegradation and to assess those DOM fractions most likely to affect treatability.

A treatability prediction concept using a combined 
HPSEC and peak-fitting approach based on the source water quality has been reported (Chow et al., 2008). This prediction was constructed using Australian water sources which exhibit high dissolved organic carbon (DOC) and high specific UV absorbance (SUVA). In contrast, Chinese water sources are generally relatively low in DOC, UV absorbance and SUVA values (Wang et al., 2010).

This article focuses on using HPSEC to provide quantitative information by applying the developed peak-fitting technique to link treatability by coagulation with the character of the DOM in the source water. In this study, the authors have applied the peak-fitting prediction concept reported earlier (Chow et al., 2008) for waters with different organic character, in order to examine the applicability and robustness of this concept for different water types. Alum $\left(\mathrm{Al}_{2}\left(\mathrm{SO}_{4}\right)_{3}\right)$ was selected as it is the most commonly used aluminium-based coagulant (Matilainen, 2010) and also allows reference back to the earlier work conducted using typical Australian high SUVA waters. Several drinking water sources in China with low SUVA were selected based on previous knowledge of DOM character. The developed peak-fitting technique was applied to these waters to predict DOC removal with alum and the results compared with the actual DOC removal determined using jar testing.

\section{Materials and methods}

\subsection{Water sources}

Six water samples were sourced from different locations throughout China (Fig. 1). These locations were selected based on the information we archived from previous Chinese water quality reports, and the aim was to cover all major Chinese river basins which represent a wide variation in surface water quality and a good representation of Chinese water sources. Furthermore, they possess the low DOC, UV absorbance and SUVA values which are representative of most Chinese water sources. Water sample $\mathrm{S} 1$ was taken from a reservoir at Heilongjiang. S2 was taken from the Songhua River which is slightly polluted by micro-organics. S3 was collected from the Pearl River. S4 was taken from downstream in the Yangtze River. S5 was from the Luan River which runs through industrial estates and residential areas in the north of China. S6 was collected from the South-to-North water diversion project. All of the six samples were from river sources. However, S1 and S6 were sampled downstream of drinking water supply reservoirs. The reservoir waters are relatively well protected and the water qualities generally good.

\subsection{Analytical methods}

The DOC concentrations were determined using a total organic carbon analyser (Phoenix 8000 system, TekmarDohrman Co., USA) by the method described in Standard Methods (APHA et al., 1998). The absorbance at $254 \mathrm{~nm}$ $\left(\mathrm{UV}_{254}\right)$ was measured using a UV/Vis spectrophotometer (UV-Vis 8500, Tecncomp Ltd., China) with a $1 \mathrm{~cm}$ quartz cell. Samples for UV absorbance and DOC were filtered

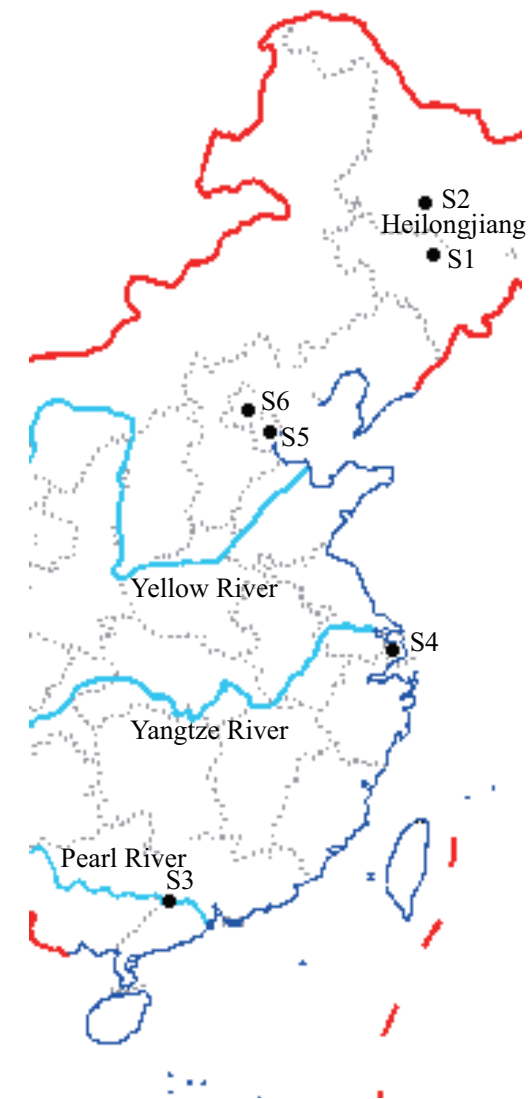

Fig. 1 Map of the study area and sampling sites in China.

through pre-rinsed $0.45 \mu \mathrm{m}$ MCE membranes (Millipore, USA). Turbidity was measured using a $2100 \mathrm{~N}$ Turbidimeter (Hach, USA).

The apparent molecular weight (AMW) of the UVabsorbing DOM constituents was determined by HPSEC. HPSEC separates DOM constituents based on a differential permeation process, according to molecular weight (hydrodynamic size). The molecular weight profile was measured using a Waters 1525 pump system and $2487 \mathrm{Du}$ al $\lambda$ Absorbance Detector at $254 \mathrm{~nm}$ (Waters Corporation, USA). Phosphate buffer $(0.005 \mathrm{~mol} / \mathrm{L})$ with $0.01 \mathrm{~mol} / \mathrm{L}$ $\mathrm{NaCl}$ was flowed through a Shodex KW802.5 packed silica column (Showa Denko, Japan) at $0.8 \mathrm{~mL} / \mathrm{min}$. This column provides an effective separation range from approximately $50 \mathrm{Da}$ to an exclusion limit of $50 \mathrm{kDa}$. AMW was derived by calibration with polystyrene sulfonate (PSS) molecular weight standards of $1.8,4.2,6.5$, and $32 \mathrm{kDa}$ (Sigma-Aldrich, USA). Samples for HPSEC separation were filtered through a $0.22 \mu \mathrm{m}$ membrane.

\subsection{Jar tests}

Alum, $\mathrm{Al}_{2}\left(\mathrm{SO}_{4}\right)_{3} \cdot 18 \mathrm{H}_{2} \mathrm{O}$ (analytical grade) was used as coagulant and jar tests were performed without $\mathrm{pH}$ control. A programmable jar test apparatus (Daiyuan Jar Test Instruments, China), having a six-paddle gang stirrer with flat paddle impellers and Gator jars was used. Water samples $(500 \mathrm{~mL})$ were added to the jars with six samples tested at a time, and the jar tester was started at rapid mixing of $300 \mathrm{r} / \mathrm{min}$ for $30 \mathrm{sec}$. The coagulant was added while stirring at $250 \mathrm{r} / \mathrm{min}$. After $2 \mathrm{~min}$ of flash mixing 
at $250 \mathrm{r} / \mathrm{min}$, the speed was reduced to $40 \mathrm{r} / \mathrm{min}$ for 10 $\mathrm{min}$. The samples were then allowed to settle for $20 \mathrm{~min}$. The settled water samples were analysed for DOC, $\mathrm{UV}_{254}$ and AMW. Compared with Australian waters, the colour of the Chinese waters was very low (mostly down to an undetectable level). Therefore, the colour parameter was not determined.

\subsection{Data analysis}

Chromatograms were analysed using a peak-fitting technique which was developed using commercially available software to resolve the overlapped peaks (Peakfit Version 4, Systat Software Inc., USA). The technique has been described elsewhere (Chow et al., 2008). The peak area of each resolved peak was used to predict the treatability of DOM.

Differences in water quality of water samples were statistically demonstrated by cluster analysis using the software package Statistica for Windows (5.1G). A hierarchical cluster method was adopted to measure the similarity (between-groups linkage) of different water clusters (Cases) with selected water quality parameters (Variables) by the calculation of the squared Euclidean distance. The shorter the distance (lower coefficients) of the cluster, the more similar are the waters in terms of water quality.

\section{Results and discussion}

\subsection{Application of the peak-fitting technique to the HPSEC results}

In previous studies, researchers determined DOM removal by comparing molecular weight profiles before and after treatment (Morran et al., 2004). In terms of evaluation of HPSEC data, the use of basic average molecular weight calculations is problematic due to the wide range of responses as well as the irregularity of the distribution. Two average molecular weight calculations are typically applied: number-averaged molecular weight $\left(M_{\mathrm{n}}\right)$ and weight-averaged molecular weight $\left(M_{\mathrm{w}}\right)$. Polydispersity $(\rho)$ is the ratio of $M_{\mathrm{w}}$ to $M_{\mathrm{n}}$. When $M_{\mathrm{n}}$ is equal to $M_{\mathrm{w}}$, then $\rho$ indicates homogeneity of the sample and for a mixture of molecules, $M_{\mathrm{n}}<M_{\mathrm{w}}$ and $\rho>1$ (Zhou et al., 2000). Generally, $M_{\mathrm{w}}$ of NOM is higher than $M_{\mathrm{n}}$. Therefore the weight-averaged molecular weight $\left(M_{\mathrm{w}}\right)$ is widely used, calculated using the following equation.

$$
M_{\mathrm{w}}=\frac{\sum_{i} n_{i} M_{i}}{\sum_{i} n_{i}}
$$

Recently, more researchers have applied a peak-fitting technique to obtain quantitative information. Moreover, this technique has been successfully used on Australian surface waters for prediction of removable or nonremovable DOM (Chow et al., 2008). The objective of this work was to evaluate how well this prediction approach can be applied to Chinese surface waters and use it to build a model to predict the DOC removal for Chinese waters.
The HPSEC profile of each raw water was processed using the developed peak fitting procedure (Chow et al., 2008). The result for one of the six source waters is shown as an example in Fig. 2, and six peaks were ascribed in the raw water DOM profile.

Peaks 1 and 2 are likely to contain a high portion of proteinaceous compounds encapsulated within a humic matrix or humic aggregates. Humic substances are considered to be rich in aromatic functional groups, and these are easily detected by UV detectors. Peak 3 may comprise fulvic acids, conjugated unsaturated acids, or keto-acids (Allpike et al., 2005). Peak 4 can be ascribed to building blocks of humic substances (Korth et al., 2004). The low molecular weight fractions (Peaks 5 and 6) are thought to be particularly important in drinking water treatment as these are poorly removed by conventional (coagulation/flocculationsedimentation-filtration) processes and are considered to be bio-available. Also, $\mathrm{UV}_{254}$ detection could underestimate the relative proportion of this fraction, which is generally considered to be unconjugated and non-aromatic in character.

\subsection{Character of the source water organics}

Source waters with different water qualities were selected based on previous knowledge of DOM character. Table 1 presents the parameters of the six source waters, and several Australian waters selected from Chow et al. (2009).

As shown in Table 1, the DOC value of Chinese waters ranged from 1.4-4.4 mg/L, while $\mathrm{UV}_{254}$ varied from 0.031 to $0.101 \mathrm{Abs} / \mathrm{cm}$. The UV absorbance and DOC values of these waters were much lower than that of the typical Australian waters. SUVA value of Chinese waters were in the range of 1.5 to $2.4 \mathrm{~L} /(\mathrm{m} \cdot \mathrm{mg})$, generally considered as low. The SUVA of waters from Hope Valley, Myponga, Morrabool and Mt Zero were 3.0, 4.0, 2.7 and 2.9 $\mathrm{L} /(\mathrm{m} \cdot \mathrm{mg}$ ), respectively (Chow et al., 2009). Two of the Chinese waters (S5 and S6) were selected as examples of micro-polluted water sources. Their low SUVA values suggest that the organics may be relatively hydrophilic in nature and possessing lower molecular weight components (Wang, 2009).

A cluster analysis using DOC, $\mathrm{UV}_{254}$ and colour of the six Chinese waters together with the four Australian waters was conducted. The diagram shown in Fig. 3 confirmed

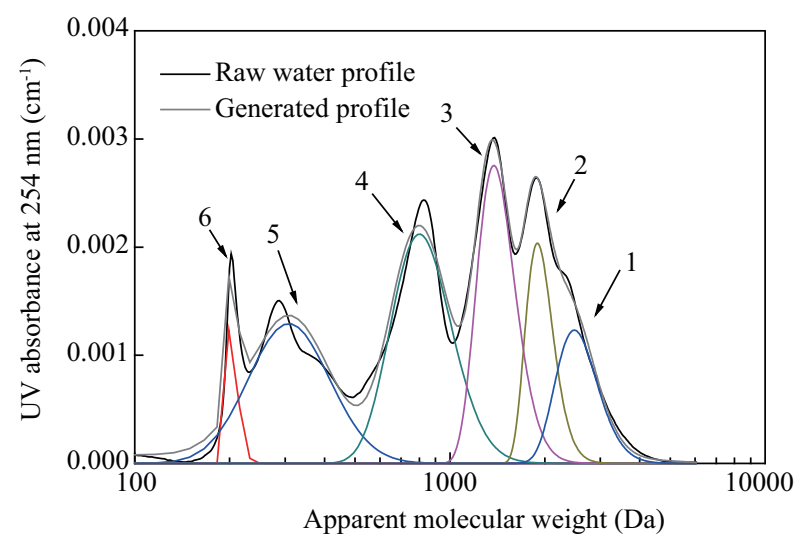

Fig. 2 Molecular weight profile of a surface water sample showing peak resolution after peak fitting. 
Table 1 Water quality parameters for selected raw drinking water sources in China and several Australian waters

\begin{tabular}{|c|c|c|c|c|c|c|c|}
\hline Sample & $\mathrm{pH}$ & $\begin{array}{l}\text { Alkalinity } \\
\left(\mathrm{mg} / \mathrm{L} \text { as } \mathrm{CaCO}_{3}\right)\end{array}$ & $\begin{array}{l}\text { Turbidity } \\
\text { (NTU) }\end{array}$ & $\begin{array}{l}\mathrm{UV}_{254} \\
(\mathrm{Abs} / \mathrm{cm})\end{array}$ & $\begin{array}{l}\text { DOC } \\
(\mathrm{mg} / \mathrm{L})\end{array}$ & $\begin{array}{l}\text { SUVA } \\
(\mathrm{L} /(\mathrm{m} \cdot \mathrm{mg}))\end{array}$ & $\begin{array}{l}M_{\mathrm{W}} \\
(\mathrm{Da})\end{array}$ \\
\hline S1 & 7.5 & 31 & 0.8 & 0.101 & 4.4 & 2.3 & 1983 \\
\hline $\mathrm{S} 2$ & 7.9 & 84 & 30 & 0.098 & 4.1 & 2.4 & 1853 \\
\hline S3 & 7.3 & 78 & 6.0 & 0.031 & 1.4 & 2.3 & 1525 \\
\hline $\mathrm{S} 4$ & 7.9 & 94 & 45 & 0.038 & 1.6 & 2.4 & 1542 \\
\hline S5 & 8.1 & 154 & 4.8 & 0.056 & 3.1 & 1.9 & 1582 \\
\hline S6 & 8.3 & 110 & 2.6 & 0.034 & 2.0 & 1.5 & 1437 \\
\hline Hope Valley, Australia ${ }^{a}$ & 8.0 & 80 & 2.9 & 0.147 & 5.0 & 3.0 & 1200 \\
\hline Myponga, Australia ${ }^{a}$ & 7.6 & 57 & 1.7 & 0.434 & 10.8 & 4.0 & 1600 \\
\hline Morrabool, Australia $^{a}$ & 7.6 & 100 & 1.7 & 0.178 & 6.9 & 2.7 & 1000 \\
\hline Mt Zero, Australia ${ }^{a}$ & 6.4 & 7 & 7.3 & 0.265 & 9.0 & 2.9 & 1000 \\
\hline
\end{tabular}

${ }^{a}$ Chow et al., 2009.

that the Chinese waters are generally clustered as one category and the Australian waters are in a different category. Further sub-categories can be obtained to compare the similarities of these water samples based on the Euclidean distance between groups.

The use of $M_{\mathrm{W}}$ to assess organic character in source waters is not expected to be a parameter sensitive enough to distinguish between different waters. This was confirmed by using the coefficient of correlation, $R^{2}$, between $M_{\mathrm{W}}$ and other parameters, such as DOC, $\mathrm{UV}_{254}$ and SUVA. For DOC and $\mathrm{UV}_{254}$, relatively high $R^{2}$ values of 0.82 and 0.89 were obtained, respectively, but for SUVA, the $R^{2}$ was only 0.3 which indicates that there is a low linear relationship between $M_{\mathrm{W}}$ and SUVA.

The comparison of the molecular weight distributions of the raw waters is shown in Fig. 4, with the UV absorbance

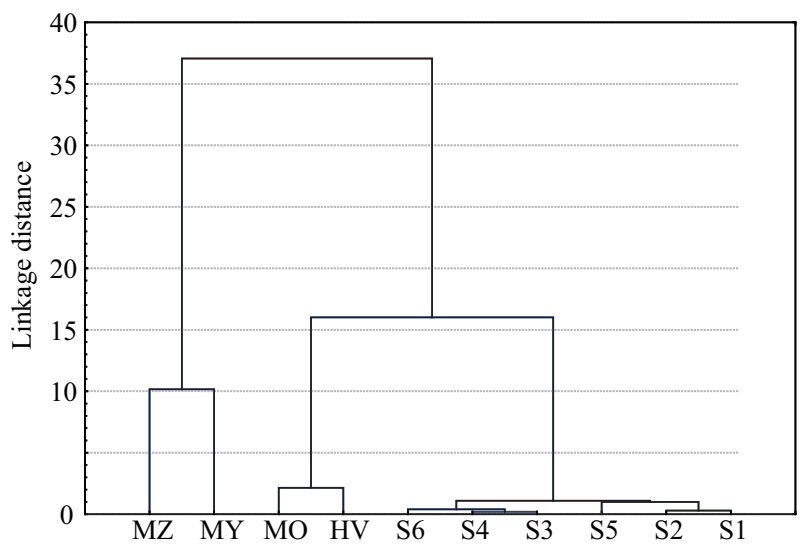

Fig. 3 Cluster analysis of the Chinese source waters, including 4 Australian waters for comparison. Chinese waters (S1-S6) and Australian waters (Hope Valley (HV), Myponga (MY), Morrabool (MD) and Mt Zero (MZ)) are compared. of each profile showing its diversity. Visual comparison can be an effective way to generally assess organic character. However, it cannot provide quantitative information to distinguish between different waters. Among all these waters, similar peak positions were observed indicating that each profile can be processed equivalently. Thus the individual peaks of $M_{\mathrm{W}}$ were found to be $2.5 \mathrm{kDa}$ (Peak 1), $1.9 \mathrm{kDa}$ (Peak 2), 1.4 kDa (Peak 3), $0.8 \mathrm{kDa}$ (Peak 4), 0.3 kDa (Peak 5), 0.2 kDa (Peak 6).

\subsection{Character of readily removable and recalcitrant organics}

Turbidity and DOC are the two main parameters for consideration in drinking water treatment in China. Two dosing levels, "conventional" and "enhanced", were chosen from the jar test results (which covered a range of alum doses) to validate the prediction (Table 2). One was based on optimised turbidity removal, a dose that is sufficient to remove the "readily removable" organics. This is described as the "conventional" coagulation dose. The residual turbidity values are given in Table 2 . They were all less than 1 NTU. The other was based on the coagulant dose at which an additional $10 \mathrm{mg} / \mathrm{L}$ reduced the DOC by less than $0.1 \mathrm{mg} / \mathrm{L}$. This is described as the "enhanced" coagulation dose. The residual part of DOM following enhanced treatment was characterized as recalcitrant organics. Table 2 shows rather low DOC removal for these waters $(2.8 \%$ to $32.3 \%)$, with DOC removal for S5 and S6 being less than 10\% using the "conventional" coagulation dose. With the "enhanced" coagulation dose, improved DOC removal was observed (29.4\% to $57.5 \%)$. The removal percentage, which was achieved by "enhanced" coagulation of the Australian waters, was mainly in $50 \%-60 \%$ range (Chow et al.,

Table 2 Water quality assessment of treatment efficiency using two doses to simulate "conventional" and "enhanced" treatment processes

\begin{tabular}{|c|c|c|c|c|c|c|c|c|c|}
\hline \multirow[b]{2}{*}{ Sample } & \multicolumn{5}{|c|}{ Conventional coagulation dose $\left(\mathrm{mg} / \mathrm{L}\right.$ as $\left.\mathrm{Al}_{2}\left(\mathrm{SO}_{4}\right)_{3} \cdot 18 \mathrm{H}_{2} \mathrm{O}\right)$} & \multicolumn{4}{|c|}{ Enhanced coagulation dose $\left(\mathrm{mg} / \mathrm{L}\right.$ as $\left.\mathrm{Al}_{2}\left(\mathrm{SO}_{4}\right)_{3} \cdot 18 \mathrm{H}_{2} \mathrm{O}\right)$} \\
\hline & $\begin{array}{l}\text { Alum } \\
\text { dose } \\
(\mathrm{mg} / \mathrm{L})\end{array}$ & $\begin{array}{l}\text { Residual } \\
\text { turbidity } \\
\text { (NTU) }\end{array}$ & $\begin{array}{l}\text { Residual } \\
\text { DOC } \\
(\mathrm{mg} / \mathrm{L})\end{array}$ & $\begin{array}{l}\mathrm{DOC} \\
\text { removal } \\
(\%)\end{array}$ & $\begin{array}{l}\text { DOC } \\
\text { removal/ } \\
\text { alum dose }\end{array}$ & $\begin{array}{l}\text { Alum } \\
\text { dose } \\
(\mathrm{mg} / \mathrm{L})\end{array}$ & $\begin{array}{l}\text { Residual } \\
\text { DOC } \\
(\mathrm{mg} / \mathrm{L})\end{array}$ & $\begin{array}{l}\mathrm{DOC} \\
\text { removal } \\
(\%)\end{array}$ & $\begin{array}{l}\text { DOC } \\
\text { removal/ } \\
\text { alum dose }\end{array}$ \\
\hline S1 & 13 & 0.80 & 3.4 & 21.3 & 0.070 & 67 & 2.0 & 57.5 & 0.030 \\
\hline $\mathrm{S} 2$ & 67 & 0.80 & 2.8 & 32.3 & 0.020 & 167 & 2.1 & 48.2 & 0.012 \\
\hline S3 & 33 & 0.52 & 1.0 & 25.9 & 0.010 & 100 & 0.9 & 33.4 & 0.005 \\
\hline S4 & 13 & 0.41 & 1.4 & 14.3 & 0.017 & 167 & 0.9 & 41.1 & 0.004 \\
\hline S5 & 13 & 0.83 & 3.0 & 2.8 & 0.006 & 100 & 2.2 & 29.4 & 0.009 \\
\hline S6 & 13 & 0.82 & 1.9 & 6.4 & 0.010 & 100 & 1.2 & 38.5 & 0.008 \\
\hline
\end{tabular}



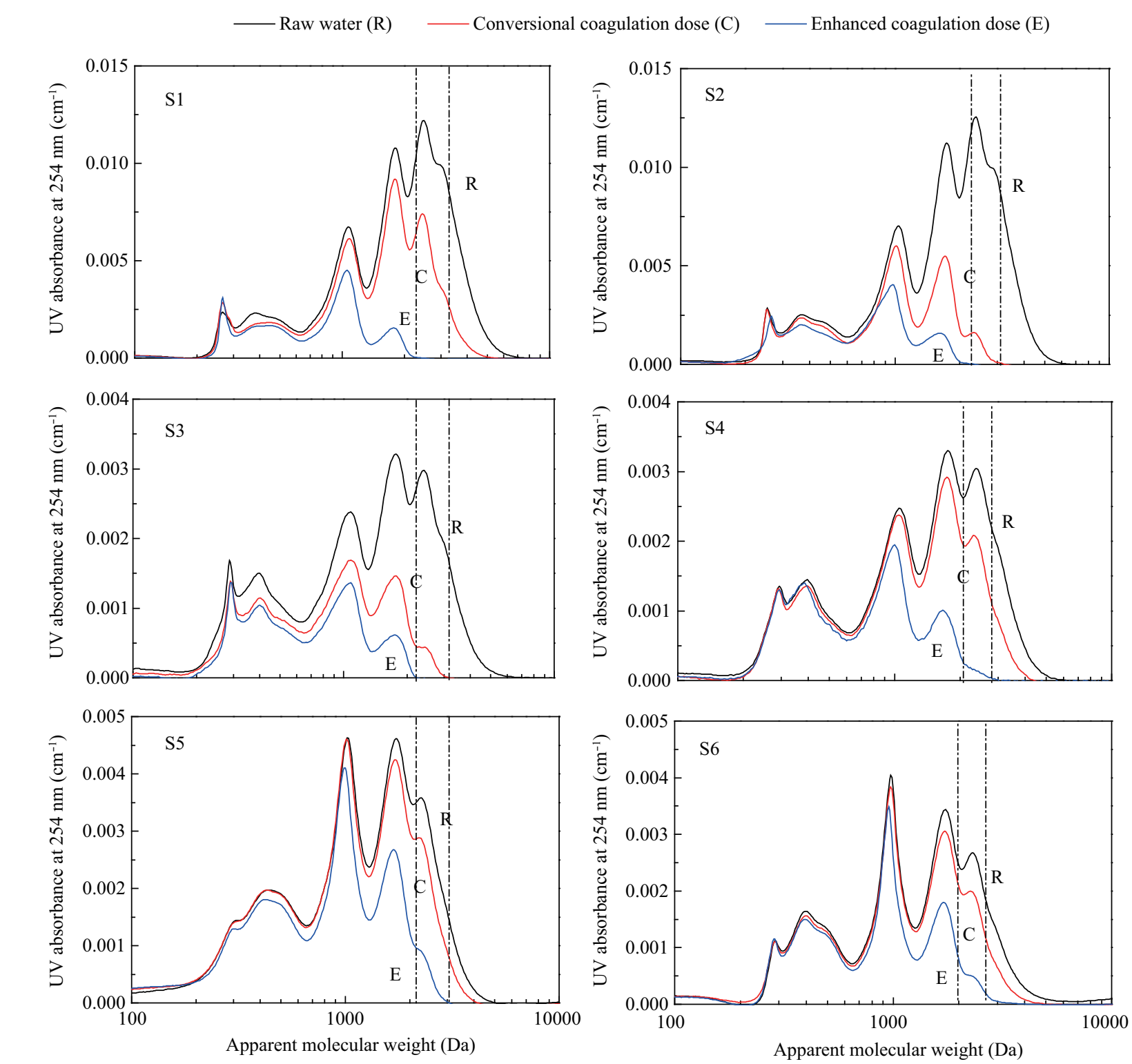

Fig. 4 Apparent molecular weight distributions for the 6 water samples for different coagulation stages.

2009). The specific DOC removal (DOC removal/alum dose) is a parameter used to assess removal performance in relation to organic character. Five of the six waters have lower specific DOC removal for the "enhanced" dose condition than the "conventional" dose condition. S5 is the exception. This indicates that the "readily removable" organics can be removed by coagulation with a relatively low alum dose and the remaining "recalcitrant" organics require a high dosage to achieve the equivalent removal. The reason that S5 was different from the others could be due to high alkalinity in the source water.

Figure 4 shows the changes in molecular weight profiles between the raw waters (before) and after coagulation at the two doses. For the "enhanced" coagulation treatment, the HPSEC results, after processing using the peak-fitting procedure, show that four peaks from the source water sample remained and the $M_{\mathrm{W}}$ of the resolved peaks were calculated to be $0.2,0.3,0.8$ and $1.4 \mathrm{kDa}$, respectively. Comparison of raw water HPSEC profiles with those for the "conventional" treatment (lower dose) demonstrated that the peak of higher molecular weight (Peak 1: 2.5 $\mathrm{kDa})$ was readily removed. When using the higher dose, Peak 1 and Peak 2 can be totally removed. Although a high dose of alum resulted in reduction of Peak 3 (1.4 $\mathrm{kDa})$ and some reduction of Peak $4(0.8 \mathrm{kDa})$, a portion of Peak 3 was still present. Both the $0.3 \mathrm{kDa}$ (Peak 5) and $0.2 \mathrm{kDa}$ (Peak 6) components exhibited only marginal removal, even with the high alum dose. These phenomena indicate that the humic acid fraction in the DOM was predominantly removed by alum treatment. These results correlate well with the overall DOC removal and SUVA reduction which also suggests that the humic acid fraction was most effectively removed.

\subsection{Prediction of DOM treatability of low SUVA surface waters}

The peaks in the chromatograms in Fig. 4 were resolved using the peak-fitting approach illustrated in Fig. 2. The results indicate that Peaks 6, 5, 4, and a component of Peak 3 are recalcitrant to removal by coagulation. 
Table 3 Comparison of predicted coagulation removal and actual DOC removal

\begin{tabular}{|c|c|c|c|c|c|c|c|c|c|c|}
\hline & \multirow{2}{*}{$\begin{array}{l}\text { Peak } 1 \\
\text { MW } 2.5 \mathrm{kDa}\end{array}$} & \multirow{2}{*}{$\begin{array}{l}\text { Peak } 2 \\
\text { MW } 1.9 \mathrm{kDa}\end{array}$} & \multirow{2}{*}{$\begin{array}{l}\text { Peak } 3 \\
\text { MW } 1.4 \mathrm{kDa}\end{array}$} & \multirow{2}{*}{$\begin{array}{l}\text { Peak } 4 \\
\text { MW } 0.8 \text { kDa }\end{array}$} & \multirow{2}{*}{$\begin{array}{l}\text { Peak } 5 \\
\text { MW } 0.3 \mathrm{kDa}\end{array}$} & \multirow{2}{*}{$\begin{array}{l}\text { Peak } 6 \\
\text { MW } 0.2 \mathrm{kDa}\end{array}$} & \multicolumn{2}{|c|}{ "Conventional" coagulation } & \multicolumn{2}{|c|}{ "Enhanced" coagulation } \\
\hline & & & & & & & Prediction $^{\mathrm{a}}$ & Actual DOC & Prediction $^{\mathrm{b}}$ & Actual DOC \\
\hline S1 & $30.5 \%$ & $24.7 \%$ & $28.7 \%$ & $12.6 \%$ & $3.2 \%$ & $0.2 \%$ & $30.5 \%$ & $21.3 \%$ & $55.2 \%$ & $57.5 \%$ \\
\hline S2 & $30.6 \%$ & $25.2 \%$ & $28.2 \%$ & $12.5 \%$ & $3.3 \%$ & $0.2 \%$ & $30.6 \%$ & $32.3 \%$ & $55.8 \%$ & $48.2 \%$ \\
\hline S3 & $23.9 \%$ & $18.4 \%$ & $29.6 \%$ & $21.5 \%$ & $6.3 \%$ & $0.3 \%$ & $23.9 \%$ & $25.9 \%$ & $42.3 \%$ & $33.4 \%$ \\
\hline S4 & $24.5 \%$ & $21.6 \%$ & $28.5 \%$ & $19.9 \%$ & $5.1 \%$ & $0.5 \%$ & $24.5 \%$ & $14.3 \%$ & $46.0 \%$ & $41.1 \%$ \\
\hline S5 & $11.9 \%$ & $23.8 \%$ & $34.2 \%$ & $20.7 \%$ & $8.7 \%$ & $0.8 \%$ & $11.9 \%$ & $2.8 \%$ & $35.7 \%$ & $29.4 \%$ \\
\hline S6 & $14.2 \%$ & $20.3 \%$ & $41.8 \%$ & $17.8 \%$ & $5.8 \%$ & $0.1 \%$ & $14.2 \%$ & $6.4 \%$ & $34.5 \%$ & $38.5 \%$ \\
\hline
\end{tabular}

Predicted coagulation removal: a "Conventional" coagulation prediction = Peak 1; ${ }^{\mathrm{b}}$ "Enhanced" coagulation prediction $=$ Peak $1+$ Peak 2.

Hence the molecular weight character of the recalcitrant organics is represented by these four peaks as defined by the peak-fitting technique. It follows that other surface water sources should show predictable treatability (DOC removal) based upon the proportion of recalcitrant organics determined through application of the same technique. By knowing that the recalcitrant fractions cannot be removed by coagulation and that the character of the recalcitrant organics can be resolved by the peak fitting procedure, it is therefore possible to predict the coagulation-removable organic components (based on DOC removal) by using the raw water HPSEC profile. The HPSEC profiles of the raw waters were analysed using the peak-fitting technique. The percentage peak area of each peak is presented in Table 3 .

In terms of predicting organic removal under "conventional" coagulation and "enhanced" coagulation conditions, we can identify that Peak 1 can be removed easily by "conventional" coagulation, Peak 2 can be reduced by "enhanced" coagulation and Peaks 3, 4, 5 and 6 are largely recalcitrant. The measured DOC removal from the experimental data is also presented in Table 3. Direct comparison showed that for the Chinese low SUVA surface waters, the predicted removals matched well with actual jar testing data ( $2 \%$ to $10 \%$ variance). This was especially true for enhanced coagulation. Using HPSEC with a UV absorbance detector essentially meant a qualitative parameter could be used to predict quantitative DOC removal in low SUVA waters, and the variance from this study is smaller than might have been expected. The prediction supports the contention that regardless of variation in the organic character and concentration of a surface water source, the molecular weight character of the post-coagulated "recalcitrant" organic matter is similar. Therefore, the prediction technique developed using high DOC and SUVA waters can also be applied successfully for prediction of the treatability of surface waters with low DOC and with low SUVA values. The peak-fitting technique gave a reasonable estimate of potential removal from the characterization of all the Chinese surface waters prior to treatment. This suggests that this technique is quite robust and may not only be applicable to any surface water source in China, but more widely throughout the world.

\section{Conclusions}

Drinking water treatment plants continually face challenges in attempting to maintain and improve water quality. An important element of water quality management is better understanding of aquatic DOM and its behaviour in water treatment processes. HPSEC is a useful and informative technique that can be applied to characterize the molecular weight profile of DOM.

DOM components with low molecular weight and low SUVA are generally recalcitrant to conventional treatment. This study also confirmed that despite differences in both concentration and character of the DOM in Chinese surface waters, the final character after alum treatment was similar. Based on this information, a peak-fitting technique for DOM removal was applied by using the HPSEC profiles of raw surface waters to predict the removable and non-removable organic fractions. The method was successful in the prediction of DOC removal from jar tests of Chinese surface water sources, including water sources with high DOC and low DOC, unpolluted and micro-polluted. Overall, prediction of DOC removal by coagulation was good, with variation between predicted and actual results averaging $10 \%$, suggesting that the technique may be generally applicable to other low SUVA surface waters. However, for other water source types such as groundwater and re-use water sources, the relationships have yet to be tested and differences in the character of the fractional components may be sufficient to alter their expected treatability.

\section{Acknowledgments}

This work was supported by the National Natural Science Foundation of China (No. 51025830) and the National Basic Research Program of (973) China (No. 2011CB933700), and the South Australian Premier's Science and Research Fund Project "Development of materials engineering solutions for treatment of MurrayDarling Basin sourced water supplies". This project was also supported by the special fund from the State Key Laboratory of Environmental Aquatic Chemistry, Project 08K08ESPCR. The authors are grateful for the kind support from the local water companies and colleagues.

\section{References}

Allpike B P, Heitz A, Joll C A, Kagi R I, AbbtBraun G, Frimmel F H et al., 2005. Size exclusion chromatography to characterize DOC removal in drinking water treatment. Environmental Science and Technology, 39(7): 2334-2342.

Andersen D O, Alberts J J, Takács M, 2000. Nature of natural organic matter (NOM) in acidified and limed surface waters. Water Research, 34(1): 266-278. 
Bolto B, Abbt-Braun G, Dixon D, Eldridge R, Frimmel F, Hesse $S$ et al., 1999. Experimental evaluation of cationic polyelectrolytes for removing natural organic matter from water. Water Science and Technology, 40(9): 71-79.

Chow C W K, Fabris R, van Leeuwen J A, Wang D S, Drikas M, 2008. Assessing natural organic matter treatability using high performance size exclusion chromatography. Environmental Science and Technology, 42(17): 6683-6689.

Chow C W K, van Leeuwen J A, Drikas M, Fabris R, Spark K M, Page D W, 1999. The impact of the character of natural organic matter in conventional treatment with alum. Water Science and Technology, 40(9): 97-104.

Chow C W K, van Leeuwen J A, Fabris R, Drikas M, 2009. Optimised coagulation using aluminium sulfate for the removal of dissolved organic carbon. Desalination, 245(13): $120-134$.

Del Vecchio R, Blough N V, 2004. On the origin of the optical properties of humic substances. Environmental Science and Technology, 38(14): 3885-3891.

Gjessing E T, Egeberg P K, Håkedal J, 1999. Natural organic matter in drinking water-The "NOM-typing project", background and basic characteristics of original water samples and NOM isolates. Environment International, 25(2-3): $145-159$.

Korth A, Fiebiger C, Bornmann K, Schmidt W, 2004. NOM increase in drinking water reservoirs- relevance for drinking water production. Water Science and Technology: Water Supply, 4(4): 55-60.

Lankes U, Lüdemann H D, Frimmel F H, 2008. Search for basic relationships between "molecular size" and "chemical structure" of aquatic natural organic matter - Answers from ${ }^{13} \mathrm{C}$ and ${ }^{15} \mathrm{~N}$ CPMAS NMR spectroscopy. Water Research, 42(4-5): 1051-1060.

Matilainen A, Vepsäläinen M, Sillanpää M, 2010. Natural organic matter removal by coagulation during drinking water treatment: A review. Advances in Colloid and Interface Science, 159(2): 189-197.

Morran J Y, Drikas M, Cook D, Bursill D B, 2004. Comparison of MIEX treatment and coagulation on NOM character. Water Science and Technology: Water Supply, 4(4): 129-137.

Nissinen T K, Miettinen I T, Martikainen P J, Vartiainen T, 2001. Molecular size distribution of natural organic matter in raw and drinking waters. Chemosphere, 45(6-7): 865-873.

Reemtsma T, These A, Springer A, Linscheid M, 2008. Differences in the molecular composition of fulvic acid size fractions detected by size-exclusion chromatography-on line Fourier transform ion cyclotron resonance (FTICR-) mass spectrometry. Water Research, 42(1-2): 63-72.

Uyak V, Ozdemir K, Toroz I, 2008. Seasonal variations of disinfection by-product precursors profile and their removal through surface water treatment plants. Science of the Total Environment, 390(2-3): 417-424.

van Leeuwen J A, Chow C, Fabris R, Withers N, Page D, Drikas $\mathrm{M}, 2002$. Application of a fractionation technique for better understanding of the removal of natural organic matter by alum coagulation. IWA Publishing, 2(5-6): 427-433.

Vuorio E, Vahala R, Rintala J, Laukkanen R, 1998. The evaluation of drinking water treatment performed with HPSEC. Environment International, 24(5-6): 617-623.

Wang D S, 2009. Enhanced Coagulation Technologies Treat Micro-Polluted Water. Science Press, Beijing, China.

Wang D S, Xing L N, Xie J K, Chow C W K, Xu Z Z, Zhao Y M et al., 2010. Application of advanced characterization techniques to assess DOM treatability of micro-polluted and un-polluted drinking source waters in China. Chemosphere, 81(1): 39-45.

Zhou Q H, Cabaniss S E, Maurice P A, 2000. Considerations in the use of high-pressure size exclusion chromatography (HPSEC) for determining molecular weights of aquatic humic substances. Water Research, 34(14): 3505-3514. 